\title{
Association between Locus of Control and Job Satisfaction in Employees: A Critical Review
}

\author{
Mr. Khagendra Nath Gangai ${ }^{1 *}$, Dr. Gopal Chandra Mahakud ${ }^{2}$, \\ Mr. Vikas Sharma ${ }^{3}$
}

\section{ABSTRACT}

Employee job satisfaction in the workplace is one of the important objectives of human resource managers and practitioners for better performance and productivity. Job satisfaction is a psychological state of human mind and it is subjective to individual experience and expectation, personality often plays an influential role. The term locus of control can be considered, a combination of one's values, beliefs, past experiences, and cultural influence one's life and behaviour. The internal-external locus of control constructs person's internal expectancies for control of reinforcement. Further, it is believed that a person's own behaviour determine the reinforcement they receive. The present research aims to investigate on the relationship between locus of control and job satisfaction and how does it influence, according to gender, culture, country, various sectors etc. The study will be based on different literature review in the area of concern. It will help us to develop a theoretical framework and a direction to solve for managerial problems of job satisfaction and performance of the employees. Dailey's (1980) found that persons with an internal locus of control were more satisfied, motivated and had a high level of participation within their jobs. Some of the researches (Kircady et al., 2002; Noor, 2002; Martin et al., 2005; and Chen and Silverthorne, 2008) revealed that, there is a relationship between job satisfaction and locus of control. The present paper will be fulfilled with the gap of various dimensions such as how it is different according to gender, country, culture, and also in different sectors.

Keywords: Internal locus of control; External Locus of control, Job satisfaction; employee performances

\footnotetext{
${ }^{1}$ Assistant Professor, Bhartiya Vidya Bhavan’s Usha \& Lakshmi Mittal Institute of Management (Bulmim), New Delhi

${ }^{2}$ Assistant Professor, Department of Applied Psychology, University of Delhi, South Campus, New Delhi

${ }^{3}$ PhD Scholar, Department of Applied Psychology, University of Delhi, South Campus, New Delhi

*Responding Author

(C) 2016 I K Gangai, G Mahakud, V Sharma; licensee IJIP. This is an Open Access Research distributed under the terms of the Creative Commons Attribution License (http://creativecommons.org/licenses/by/2.0), which permits unrestricted use, distribution, and reproduction in any Medium, provided the original work is properly cited.
} 
Almost all human beings always strive for satisfaction in every aspect of life. But in the organizational context, this may be related to striving towards securing a good job, with a good pay and high job satisfaction. Satisfaction with job has always been an important aspect for practitioners, human resource managers and academicians because of the reason that job satisfaction significantly affects major organizational outcomes, such as individual performance, organizational productivity, employee absenteeism, employee commitment, job involvement, employee engagement and employee turnover.

Locus of Control (LOC) is originated by Julian Rotter, in the year 1950 and is classified into two major categories such as Internal and External Locus of control. "Internal control" is the term used to describe the belief that control of future outcomes resides primarily in oneself. On the other hand "external control" refers to the expectancy that control is outside of oneself, either in the hands of other powerful people or due to fate and/or chance. According to the study of Kabanoff and O'Brien (1980) "Person having an internal locus of control if will be engaged in leisure activities will help to develop more personal control. Because the internals believe in and seek personal control they exhibit less social influence than do externals". The finding of the study is the extension work of Crowne and Liverant (1963) and the study of Hjelle and Couser (1970). Simply, it can be said that people who develop an internal LOC believe they are responsible for their own success. Those with external LOC believe that fate, luck or outside influences determine their success (Gershaw, 1989). Lack of competence, confidence, and motivation can keep people from taking external control of their lives. The characteristics of Internal and external locus of control is illustrated in Table-1.

\section{Table-1 Characteristics of Locus of Control Employees}

\begin{tabular}{|c|c|}
\hline Internal LOC Employees & External LOC Employees \\
\hline 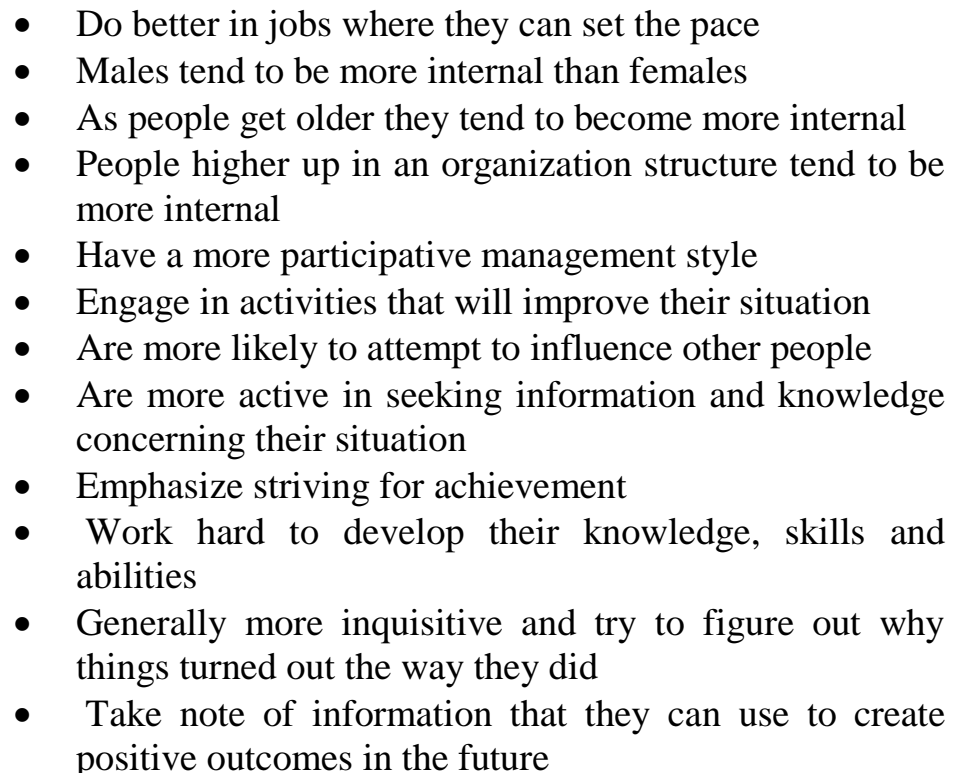 & $\begin{array}{l}\text { - Tends to stay in jobs that they are } \\
\text { dissatisfied with longer } \\
\text { - } \text { Works better when pace is automated } \\
\text { - } \text { Feel victimized by illness or stress } \\
\text { - } \text { Tends to be negative } \\
\text { - } \text { Are more influenced by social } \\
\text { - } \text { surroundings } \\
\text { Believes success or failure is a result } \\
\text { - } \text { of luck, fate or chance } \\
\text { - Asually humble and agreeable } \\
\text { - } \text { Acknowledges and shows praise to } \\
\text { - Taid-back and easy going } \\
\text { Tend to like and follow detailed } \\
\text { directions }\end{array}$ \\
\hline
\end{tabular}




\section{THEORETICAL FRAMEWORK:}

Locus of Control (LOC) in the workplace differentiates employees who believe they can exercise control over their work and their environment through their own actions employees who are more or less self-reliant. The distinguishing difference in the belief of personal control between internals and externals, will affect performance levels. Studies (e.g. Judge, 1997) supported the direct impact of LOC on individual behaviors that impact job performance and job satisfaction in the workplace. Similarly, the study of Spector, (1982) suggested that individuals with internal LOC should be more job satisfied because they are less likely to stay in a dissatisfying job and are more likely to be successful in an organization. Recognizing that job satisfaction is predictive of job turnover, it should come as no surprise that internals take action and would be expected to look for other opportunities (either internally or with another company) if in a dissatisfying job. On the hand externals tend not to take action and therefore even if they are dissatisfied they may stay on the job until environmental factors force them to leave.

\section{METHODOLOGY:}

The present article is a conceptual paper based on literature review. The methodology revolves majorly on the selection and rejection of research articles. The researchers studied numbers of research articles in the area of concern. A detailed and critical analysis of the research articles in the area of concern were analysed for the preparation of the present article. Only the relevant articles those fulfilled the search requirement, whether qualitative or quantitative were kept in the pool. Generally, a thumb rule was used in which we treated Job satisfaction as a dependent variable and factors that influenced by Locus of control is independent variable. Besides that, peer reviewed articles, working papers and dissertations are also included in the pool. A total of 100 articles were reviewed and finally fifty numbers of research and review articles were included in the pool of selection.

\section{LITERATURE REVIEW:}

It is very clear to say that, there is a positive association between Locus of control and Job satisfaction of employees at the workplace. Numbers of studies (Table-2) indicate the positive relationship between Locus of Control and Job satisfaction of employees in different organizational sectors. The study conducted by Aghaei, Asadollahi, Moezzi, Beigi, and Parvinnejad (2013) aimed to find out the role locus of control in relationship with job satisfaction

and job burnout. A total of 310 employees were randomly participated in their study. The study included the tests of occupational exhaustion, personality type, locus of control and occupational satisfaction in them. Then the researcher's randomly selected 40 subjects from all 52 people who have gained a mark more than one and a standard deviation over mean in occupational exhaustion test, and again divided them randomly into two groups; an experimental group and a control group, each group having 20 subjects. The experimental group participated in the courses of Stress Inoculation Training consisting of nine 45 minute sessions. The techniques and methods used for experimental group are: getting acquainted with career stresses, discussion about consequences and difficulties of stress, clarifying the role of thoughts and beliefs in 
revelation of stress and its relationship to occupational exhaustion and job dissatisfaction, administrating techniques of mental imagery, cognitive reproduction, muscular relaxation, problem solving, thought stopping, self-sufficiency etc. The results indicated that: Firstly, there is a significant positive relation between occupational exhaustion and personality type. Secondly, there is a significant inverse relationship between occupational exhaustion and locus of control. Thirdly, there is a considerable inverse relation between occupational exhaustion and occupational satisfaction $(\mathrm{P}<0 / 01)$. The results of multiple regression analysis indicated that personality type, locus of control and occupational satisfaction can predict occupational exhaustion. In gradation, the first is occupational satisfaction, locus of control is the second, and personality type is the third. The results from the experimental group and control group express that Stress Inoculation Training method is effective in reducing occupational exhaustion $(\mathrm{P}<0 / 01)$ and increasing occupational satisfaction $(\mathrm{P}<0 / 01)$. Likewise, Karimi \& Alipour (2011) investigated theoretically how the locus of control can reduce occupational stress in the workplaces so as to have an effective performance improvement.

In a similar study conducted by Vijayashree and Jagdischchandra (2011) stated that internal/external locus of control impacts job satisfaction. The aim of the study was to analyze the type of locus of control and its relation to job satisfaction. Further, the study has focused on organization to understand and know what type of locus of control their employees has and how it has an impact on job satisfaction. The results indicate that there was a positive correlation between internal locus of control and job satisfaction as well as between External (other) locus of control and job satisfaction. In case of External (Chance) locus of control and job satisfaction there exists a partial positive correlation. There is no significant relationship between internality and demographic factors like gender and education. There is also no significant relationship between externality (chance) and demographic factors like gender and education.

In another study by Mahajan and Kaur (2012) it is found that, the relationship between locus of control of college teachers and their job satisfaction. A sample of 150 teachers was selected from the different colleges of Amritsar city in Punjab, India. The study reveals a significant relationship between locus of control and job satisfaction of college teachers. Among male and female teachers, male teachers with high job satisfaction possess a better locus of control as compared to female college teachers with high job satisfaction.

On the other hand the study of Dhole and Tipnis (2013) revealed that the feeling of satisfaction at the workplace, such as work- family conflict, injustice perception and social support, immediate changes in personal or vocational life, work culture, stress and locus of control. Among these variables, stress and locus of control are more important and frequent predators of job satisfaction. The total sample consists of 60 employees form manufacturing industry India. The result reveals that there is negative relationship between locus control and job satisfaction. The study of Chhabra (2013) aimed to see if locus of control moderates the relationship between job satisfaction and organizational commitment. The sample of the study was 449 Indian IT professionals. Hierarchical multiple regression analysis of the result showed that job satisfaction 
and internal locus of control was positively related to organizational commitment. Locus of control was found to moderate the relationship between job satisfaction and organizational commitment such that the relationship was stronger for internals than for externals. It has important implications for human resource development in the IT sector. Managers should use strategies to achieve high job satisfaction and organizational commitment. They must be aware of the moderating role which different personality attributes play in the relationship between job satisfaction and organizational commitment.

In an international study by Hans et al (2014) affirmed that the Locus of Control and level of Job Satisfaction among private international school teachers in Sultanate of Oman. The descriptive research design was adopted and simple random sampling was chosen for study. The population comprised of eight private international schools in Muscat. The study identified the phenomena related to Locus of Control and Job Satisfaction among teachers in Sultanate of Oman. Demographic factors such as gender, age and experience were influenced on Locus of Control and Job Satisfaction. The result indicated that the teachers of private international school were primarily driven by internal locus of control and their level of job satisfaction is high. Male teachers were found to have slightly more internal locus of control compared to the female as the score for male teachers. The teachers of private international school were highly satisfied with their jobs as the percentages of satisfaction in all the age groups are high. The teachers with different years of their experience in private international school were found satisfied with their jobs as the percentage of satisfaction was more than dissatisfaction level.

In another study of Hans et al (2013) also stated that the Locus of Control and level of Job Satisfaction among middle level management in semi-government organizations in Sultanate of Oman. The Sampling fraction of $40 \%$ was taken to divide the population into a homogeneous subgroup comprising of eight sectors as Oil and Gas Sector, Banking and Investment Sector, Transport, Aviation and Ports Sectors, Industry Sector, Tourism Sector, Energy Sector, Services Sector and Exhibitions Sector. These sectors comprised of 25 organizations. The strata were mutually exclusive. The study identified the phenomena related to Locus of Control and Job Satisfaction in semi-government organization's middle level employees in Sultanate of Oman. Demographic factors such as gender, age, and years of experience were influenced on Locus of Control and Job Satisfaction and result indicated that the middle level management employees in semi-government organizations were primarily driven by internal locus of control and most of the employees in the sector scored low in job satisfaction scale. It was found that female and male employees of middle level management were controlled by internal locus of control. The lowest score in chance control and powerful other conferred that they disagreed that the outcome of their work was controlled by chance or powerful other. Male employees were found to have slightly more Internal locus of control compared to female. It was observed that with the increase in age, locus of control increased. Middle level employees at all the age groups were found dissatisfied. 
In a study conducted by Singh and Dubey (2011) on 210 managers from different private sector organizations to examine the role of stress (role stress) and locus of control on job satisfaction. In this study, stress and locus of control were treated as predictor variables, whereas satisfaction was used as a criterion variable. The results of correlation indicated that role overload was significantly negatively correlated with satisfaction with management and total satisfaction; role ambiguity was significantly negatively correlated with satisfaction with management; and role conflict was significantly negatively correlated with satisfaction with management and total satisfaction. Overall stress was significantly negatively correlated with satisfaction with management and total satisfaction. Locus of control was significantly negatively correlated with satisfaction with management and total satisfaction. The results of step-wise multiple regression analysis showed that the total stress contributed $7.4 \%$ variance in explaining satisfaction with management, and role conflict contributed $7.1 \%$ variance in explaining total satisfaction.

The higher levels of absenteeism and turnover that call centers across the globe experience due to employee job dissatisfaction have led to a renewed interest in the role that personality traits play in the service industry. In this regard a study conducted by Carrim et al. (2006) to investigate the relationship between call centre agents' job satisfaction and their locus of control orientation. A sample of 187 call centre agents from a municipality in Gauteng participated. The results revealed that the call centre agents with an internal locus of control appear to experience significantly higher, extrinsic and intrinsic job satisfaction compared to call centre agents with an external locus of control. The results further suggested that the male and female participants did not differ with regard to their general and intrinsic levels of job satisfaction and that participants with post-school qualifications experienced lower levels of intrinsic job satisfaction.

Similarly the study of Wang, Bowling \& Eschleman (2010) was also intended to examine the hypothesized consequences of work and general locus of control. As expected, work locus of control generally yielded stronger relationships with work-related criteria (e.g., job satisfaction, affective commitment, and burnout) than the general locus of control. We also found some evidence that general locus of control yielded relatively stronger relationships with general criteria (e.g., life satisfaction, affective commitment, and burnout). Regression analysis found several unique effects for both work and general locus of control.

The empirical study of Igbeneghu \& Popoola (2011), on a sample of 512 in Nigeria Hospital and evidence to show that work locus of control indicates that personality variable, has a significant inverse relationship with organizational commitment. But the combination of work locus of control and job satisfaction has significant influence on the organizational commitment of medical records personnel in university teaching hospitals in Nigeria. In this regard a contradictory result also found from the study of Coleman, Irving \& Cooper, (1999) that implied the individuals with an external locus of control (LOC) are less likely to be committed to their organizations. More recent work on organizational commitment has suggested that commitment is not a unidimensional construct and can take several forms (e.g., affective and continuance). Using a sample of 232 employees of a Canadian governmental agency, we examined the 
relations between LOC and two different forms of organizational commitment that have been found to have different antecedents and consequences. We found that internal LOC was associated with affective commitment and external LOC was associated with continuance commitment.

In an Indian study Srivastava, (2009) conducted a study a sample of 200 managers belonging to private sector organizations and to analyzed moderating effects of Locus of Control on the relationship between organisational role stress and managerial effectiveness. In this regard the researcher found out that organisational role stress was negatively related to Managerial Effectiveness and Internal Locus of Control moderated organisational role stress and Managerial Effectiveness relationship. Similar study, Srivastava (2011) aimed to study on the relationship between Job Burnout and Managerial Effectiveness as moderated by Perceived Organisational Support and Locus of Control. A sample of 550 Middle level managers belonging to Private Sector Organizations was participated in this study. The result of the study revealed that Job Burnout was negatively related to Managerial Effectiveness and Perceived Organisational Support and Locus of Control moderated Job Burnout and Managerial Effectiveness relationship.

In another study by Dayo (2012) investigated the influence of locus of control and job satisfaction on perceived non- teaching staff's productivity in higher institutions in Ogun State of Nigeria. A total of 341 respondents were selected for the study, the findings of the study revealed that locus of control and job satisfaction were found to have jointly contributed to perceived nonteaching staff's productivity in selected higher institutions in Ogun State of Nigeria. Also, job satisfaction was found to have significantly influenced perceived non- teaching staff's productivity. Moreover, locus of control was not significantly related to perceived non- teaching staff's productivity. Based on the findings of the study, it is recommended that non- teaching staffs ' should be exposed to skill development programme on the job and on a continuous basis in order to update their skills, knowledge, values, and receive proper orientation regarding the correlate of organizational productivity. This will enable them aware of the influence of the working environment on their productivity and over the danger of attributing productivity to self efficacy and locus of control.

In a study related to leadership qualities and its relation to locos of control Dharani \& Peters (2012) investigated the impact of locus of control, a psychological, social learning theory that is rigorously researched for its implications on leadership qualities, on the level of happiness of an individual. A total of 114 participants were participated in the study. The results concluded that a maximum level of happiness is achieved by individuals with a balanced locus of control expectancy - a mix of internal and external locus of control, alternatively known as 'bi-local expectancy'. Further Omari, K’Obonyo, and Kidombo (2012) explored the effect of human resource practices in the relationship between locus of control and employee outcomes. Personality is a stable characteristic that employees bring to the work place. It is presumed that locus of control will influence employee outcomes, but the strength of its effect will be influenced by the implementation of human resource practices in the organization. Human 
resource practices were expected to moderate these relationships. Predicted relationships were drawn from prior theory that identified how human resource practices influence employee outcomes and on how locus of control affected employee outcomes. The individual's locus of control was evaluated based on the external and internal continuum. Employee outcomes studied were job satisfaction, trust, employee commitment and organizational citizenship behaviour. Results obtained from 181 respondents in Kenyan public corporations indicated that human resources practices influenced the relationship between locus of control with job satisfaction, employee commitment, trust and organizational citizenship behaviours.

Bosman, and Buitendach, (2005) investigated the relationship between job insecurity, work locus of control and dispositional optimism of employees working in two financial institutions $(\mathrm{N}=$ 605 ) in Gauteng. Results showed a practically significant relationship between job insecurity and work locus of control, implying that external locus of control was associated with higher levels of job insecurity. It was furthermore found that increased levels of dispositional optimism were associated with decreased levels of job insecurity. Both work locus of control and dispositional optimism held predictive value with regard to job insecurity whilst controlling for the impact of demographic variables such as gender age, qualification and race. The manpower coordinates with the agency workers needs the correlation between agency workers. In this context Shy \& Hsin (2013) conducted a study on 212 participants in Taiwan. The aim of the study was to find out the relationship of external locus of control on relationships among Coping Behavior on Job Satisfaction. The finding of the study is that there is significant correlation between agency workers, External Locus of Control and Job Satisfaction. Coping Behavior significantly influences Job Satisfaction, and External Locus of Control significantly influences Job Satisfaction. Moderating effect Coping Behavior between External Locus of Control and Job Satisfaction is supported.

Millet (2005) studied in four stages on the impact of the psychological construct internal versus external control of reinforcement on Swedish working life in two distinct areas. The Locus of control was found to exert a notable influence on the differences between the individuals in the study sample, with persons of external locus of control having a less favorable point of departure at the start of vocational rehabilitation compared to other groups. The locus of control is a factor of some importance for the vocational rehabilitation process as well as the management of small firms, and as such has a definite role to play in working life. It is argued that differences found between persons of internal and those of external orientation in the four studies presented are well described in the general statement that 'internals' have a higher degree of generalized expectancy that reinforcements are contingent upon their own behaviour than 'externals' and that this is crucial to explaining the differences between the cognitive processes and behaviour of the two categories. Internals' attitudes create "spaces of action” that are in themselves opportunities that can be utilized for the achievement of goals. Externals, on the other hand, have greater difficulties in creating and utilizing "spaces of action". Important is the assumption that a person's locus of control can be changed, thereby making the concept suitable for application in practical situations in working life through suitable interventions in the environment. 
Spector et al. (2002) find out that, the relationship among the work locus of control, job satisfaction, psychological strain, physical strain, and individualism/collectivism. The salutary effects of perceived control on well-being are universal was supported because relations of work locus of control with well-being at work. Furthermore, the individualism/collectivism level of each sample did not moderate the magnitude of correlations of work locus of control with measures of well-being. Findings indicate that control beliefs contribute to well-being universally. Judge and Bono (2001) conducted meta-analytic results of the relationship of 4 traits-self-esteem, generalized self-efficacy, locus of control, and emotional stability (low neuroticism) - with job satisfaction and job performance. With respect to job satisfaction, the estimated true score correlations were 0.26 for self-esteem, 0.45 for generalized self-efficacy, 0.32 for internal locus of control, and 0.24 for emotional stability. With respect to job performance, the correlations were 0.26 for self-esteem, 0.23 for generalized self-efficacy, 0.22 for internal locus of control, and 0.19 for emotional stability. In total, the results based on 274 correlations suggest that these traits are among the best dispositional predictors of job satisfaction and job performance.

Reed, Kratchman, \& Strawser (1994) investigated the impact of locus of control and gender on the experiences and practices of accounting professionals. Also considered the impact of role overload, inter-role conflict, and coping behaviour on these attitudes. Suggests that a complex set of forces creates differences in the extent to which an individual encounters, and is successfully able to contend with, both role overload and inter-role conflict. Gender differences were observed in the accountants' expressions of housekeeper role overload, volunteer role overload, and inter-role conflict between work and spouse. Locus of control differences was present in the perceived conflict between works and self. Locus of control and gender interacted to produce differences in accountants' expressions of overload and leisurite role overload expressed less satisfaction with their current positions and greater intentions to search for alternative opportunities. In this regard the study suggests that the accounting environment may still be inhospitable for certain women attempting to realize multiple work and family obligations.

Table-2 Relationship between Locus of control and Job satisfaction

\begin{tabular}{|c|c|c|c|c|c|}
\hline Authors & Country & $\begin{array}{l}\text { Sectors/ } \\
\text { Industry }\end{array}$ & Gender & Methods & $\begin{array}{l}\text { Relationship between } \\
\text { Locus of Control \& Job } \\
\text { Satisfaction }\end{array}$ \\
\hline $\begin{array}{l}\text { Aghaei et al } \\
(2013)\end{array}$ & Iran & Private & - & $\begin{array}{l}40 \text { Sample; } \\
\text { Experimental } \\
\text { techniques }\end{array}$ & Positively correlated \\
\hline $\begin{array}{l}\text { Vijayashree \& } \\
\text { Jagdischchandra } \\
\text { (2011) }\end{array}$ & India & PSU & $\begin{array}{l}\text { Male -58 } \\
\text { Female - } \\
15\end{array}$ & $\begin{array}{l}73 \text { Sample; } \\
\text { Quantitative } \\
\text { Techniques }\end{array}$ & $\begin{array}{l}\text { Internal \& External locus } \\
\text { of control is positively } \\
\text { correlated }\end{array}$ \\
\hline
\end{tabular}


Association between Locus of Control and Job Satisfaction in Employees: A Critical Review

\begin{tabular}{|c|c|c|c|c|c|}
\hline $\begin{array}{l}\text { Mahajan \& Kaur } \\
\text { (2012) }\end{array}$ & India & Education & $\begin{array}{l}\text { Male-75 } \\
\text { Female-75 }\end{array}$ & $\begin{array}{l}150 \text { Sample; } \\
\text { Quantitative } \\
\text { Techniques }\end{array}$ & $\begin{array}{l}\text { Internal \& External locus } \\
\text { of control is positively } \\
\text { correlated }\end{array}$ \\
\hline $\begin{array}{ll}\text { Dhole } & \& \\
\text { Tipnis(2013) } & \end{array}$ & India & Manufacturing & - & $\begin{array}{l}60 \text { Sample; } \\
\text { Qualitative } \\
\text { Techniques }\end{array}$ & Negatively correlated \\
\hline Chhabra (2013) & India & IT & $\begin{array}{l}\text { Male-335 } \\
\text { Female- } \\
114\end{array}$ & $\begin{array}{l}49 \text { Sample; } \\
\text { Quantitative } \\
\text { Techniques }\end{array}$ & $\begin{array}{l}\text { Internal LOC are } \\
\text { more satisfied with their } \\
\text { jobs than employees with } \\
\text { external LOC }\end{array}$ \\
\hline Hans et al (2014) & Oman & Education & - & $\begin{array}{l}\text { 54 Sample; } \\
\text { Qualitative } \\
\text { Techniques }\end{array}$ & $\begin{array}{l}\text { Internal LOC are } \\
\text { more satisfied with their } \\
\text { jobs than employees with } \\
\text { external LOC }\end{array}$ \\
\hline Hans et al (2013) & Oman & PSU & - & $\begin{array}{l}100 \text { Sample; } \\
\text { Qualitative } \\
\text { Techniques }\end{array}$ & $\begin{array}{l}\text { Internal LOC are } \\
\text { more satisfied with their } \\
\text { jobs than employees with } \\
\text { external LOC }\end{array}$ \\
\hline $\begin{array}{l}\text { Singh and Dubey } \\
\text { (2011) }\end{array}$ & India & Private & - & $\begin{array}{l}210 \text { Sample; } \\
\text { Quantitative } \\
\text { Techniques }\end{array}$ & Positively correlated \\
\hline $\begin{array}{l}\text { Carrim et al.( } \\
\text { 2006) }\end{array}$ & $\begin{array}{l}\text { South } \\
\text { African }\end{array}$ & Call center & $\begin{array}{l}\text { Male - } \\
34.76 \% \\
\text { Female- } \\
65.24 \%\end{array}$ & $\begin{array}{l}187 \text { Sample; } \\
\text { Quantitative } \\
\text { Techniques }\end{array}$ & Positively correlated \\
\hline $\begin{array}{l}\text { Wang, Bowling } \\
\& \quad \text { Eschleman } \\
(2010)\end{array}$ & USA & - & - & $\begin{array}{l}\text { 124 Sample: } \\
\text { Exprimental } \\
\text { Techniques }\end{array}$ & Positively correlated \\
\hline $\begin{array}{l}\text { Igbeneghu \& } \\
\text { Popoola (2011) }\end{array}$ & Nigeria & Hospital & - & $\begin{array}{l}512 \text { Sample; } \\
\text { Qunatitaive } \\
\text { Techniques }\end{array}$ & Positively correlated \\
\hline $\begin{array}{l}\text { Srivastava } \\
2009,2011)\end{array}$ & India & Private & - & $\begin{array}{l}200 \& 550 \\
\text { Sample }\end{array}$ & $\begin{array}{l}\text { Internal Locus of control } \\
\text { is more satisfied with }\end{array}$ \\
\hline
\end{tabular}




\begin{tabular}{|c|c|c|c|c|c|}
\hline & & & & $\begin{array}{l}\text { Qunatitaive } \\
\text { Techniques }\end{array}$ & $\begin{array}{l}\text { their jobs and hence they } \\
\text { are more committed } \\
\text { towards } \\
\text { Organization. }\end{array}$ \\
\hline Dayo(2012) & Nigeria & $\begin{array}{l}\text { Higher } \\
\text { Education } \\
\text { insitutute }\end{array}$ & - & $\begin{array}{l}314 \text { Sample; } \\
\text { Qunatitaive } \\
\text { Techniques }\end{array}$ & Positively correlated \\
\hline Kulcarni(1983) & USA & $\begin{array}{l}\text { Bank and } \\
\text { Insurance }\end{array}$ & - & $\begin{array}{l}200 \text { Sample; } \\
\text { Qunatitaive } \\
\text { Techniques }\end{array}$ & $\begin{array}{l}\text { Negatively correlated } \\
\text { with External locus of } \\
\text { control and positively } \\
\text { correlated with internal } \\
\text { locus of control. }\end{array}$ \\
\hline
\end{tabular}

Kulcarni (1983) had compared between job satisfaction and Rotter's Internal-External Locus of Control of 200 bank and insurance company employees. Results shown that there are a significant negative relationship between job satisfaction and external locus of control, and similarly, with higher internal locus of control reported higher job satisfaction. Results indicated that the locus of control dimension can serve as a potential personality variable that is capable of determining the goal-oriented behaviors of employees; the locus of control construct may also facilitate understanding of individual differences in organizational behavior.

\section{DISCUSSION:}

The review indicates that locus of control is an important variable in considering the job satisfaction of the employees in different sectors. The larger numbers of studies conducted in this area indicate the importance of understanding the mediating role of locus of control in the overall job satisfactions of the employees. The majority of the studies have highlighted a positive correlation between the internal and external locus of control with the job satisfaction of employees (e.g. Aghaei et al, 2013; Fushimi, 2013; Singh and Dubey, 2011; Carrim et al., 2006; Wang, Bowling \& Eschleman, 2010; Igbeneghu \& Popoola, 2011; Dharani \& Peters 2012). Further, the studies have demonstrated that having an internal locus of control is more conducive for the job satisfaction than the external locus of control (e.g. Chhabra, 2013; Hans et al., 2013; Hans et al., 2014).

However, most of the studies were based on assessments at the cross sectional level. Therefore, more studies are to be conducted which studies the longitudinal relationship between the role of locus control and job satisfaction. Moreover, other factors such as personality, experience and training may also mediate the relationship between the locus of control and job satisfaction. Hence, more research required to establish the nature of the relationship between locus of control and job satisfaction of employees. This study has implication for personal selection, job performance and organizational decision making. 


\section{CONCLUSION:}

In any organisation, work performance is mostly based on employee job satisfaction. A satisfied person can better perform I both home and workplace than to a person with dissatisfaction. In this regard it is important to find out the relationship of locus of control and the job satisfaction of employees working in different organizational sectors. After investigating and critically analyzing the numbers of research studies in the present article, it is found that people having an internal locus of control are more satisfied with their jobs than to people with an external locus of control. The findings from different studies indicates people having an internal locus of control are more satisfied with their jobs, they are more productive and more work oriented than to their counterparts those have external locus of control. In this regard during the time of screening, appointment in any organizational sector the test of locus of control can be suggested especially for administrative jobs in any organizational sector.

\section{REFERENCES:}

Aghaei, M., Asadollahi, A., Moezzi, A. D., Beigi, M., \& Parvinnejad, F. (2013). The relation between personality type, locus of control, occupational satisfaction and occupational exhaustion and determining the effectiveness of stress inoculation training (SIT) on reducing it among staffers of Saipa Company. Research Journal of Recent Science, 2(12), 6-11.

April, K. A., Dharani, B., \& Peters, K. (2012). Impact of locus of control expectancy on level of well-being. Review of European Studies, 4 (2), 124-137.

Bosman, J., \& Buitendach, J. H. (2005). Work locus of control and dispositional optimism as antecedents to job insecurity. SA Journal of Industrial Psychology, 31 (4), p-17-23.

Carrim, N., Basson, J., \& Coetzee, M. (2006). The relationship between job satisfaction and locus of control in a South African call centre environment. South African Journal of Labour Relations, 30 (2), 66-81.

Chhabra, B. (2013). Locus Of Control as A Mode Tor In The Relationship Between Job Satisfaction And Organizational Commitment: A Study Of Indian It Professionals. Organizations and Markets In Emerging Economies, Vol. 4, No. 2 (8), 25-41.

Coleman, D. F., Irving, G. P., \& Cooper, C. L. (1999). Another look at the locus of controlorganizational commitment relationship: it depends on the form of commitment. Journal of Organizational Behavior, 20 (6), 995-1001.

Crowne, D. P., \& Liverant, S. (1963). Conformity under varying conditions of personal commitment. The Journal of Abnormal and Social Psychology, 66 (6), 547.

Dayo. I. A. (2012). Locus of control and job satisfaction as predictors of Perceived non-teaching staff's productivity in higher institutions in Ogun state, Nigeria, Global Advanced Research Journal of Management and Business Studies, 1 (6), 181-187.

Dhole, V., \& Tipnis, J. (2013). Role of Stress and Locus of Control on Job Satisfaction among Employees with Special Reference to Manufacturing Industry. International Journal Of Social Sciences \& Interdisciplinary Research, 2 (1), 93-105. 
Fushimi, M. (2013). Effects of job satisfaction and locus of control on psychological distress in Japanese employees. Reserved from

http://www.iconceptpress.com/download/paper/13032908171207.pdf on dated 22-122015

Gershaw, D. A (1989). Line on life: locus of control. Retrieved 11/01/2015 from http://virgil.azwestern.edu/ daq/lol/control locus.html

Hans, A., Mubeen, A. S., \& Ghabshi, A. (2013). A study of Locus of Control and Job Satisfaction in semi government organizations in Sultanate of Oman. The SIJ Transactions on Industrial, Financial \& Business Management, 1 (2), 93-100.

Hans, A., Mubeen, S. A., \& Al Ghabshi, M. A. S. (2014) A Study on Locus of Control and Job Satisfaction In Private International Schools In Sultanate of Oman, International Journal of Application or Innovation in Engineering \& Management (IJAIEM), Volume 3, Issue 1, 91-98.

Hjelle, L. A. \& Clouser, R. (1970), "Internal-Ex-ternal Control upon Changes in Smoking Behavior," Psychological Reports, 26 (April), 562.

Igbeneghu, B. I., \& Popoola, S. O. (2011). Influence of Locus of control and job satisfaction on Organizational Commitment: A Study of Medical records personnel in University teaching hospitals in Nigeria. http://digitalcommons.unl.edu/cgi/viewcontent.cgi?article=1606\&context=libphilprac

Judge, T. A., \& Bono, J. E. (2001). Relationship of core self-evaluations traits-self-esteem, generalized self-efficacy, locus of control, and emotional stability-with job satisfaction and job performance: A meta-analysis. Journal of applied Psychology, 86 (1), 80-92.

Kabanoff, B. \& O'Brien, G. (1980). Work and leisure: a task attributes analysis. Journal of Applied Psychology, 65 (5), 596-609.

Karimi, R., \& Alipour, F. (2011). Reduce job stress in organizations: Role of locus of control. International Journal of Business and Social Science, 2 (18), 232-236.

Kulcarni, A. V. (1983). Relationship between Internal vs. External locus of control and job satisfaction. Journal of Psychological Researches, 27 (1), 57-60.

Mahajan, N., \& Kaur, J. (2012). Relation between locus of control of college teachers and their job satisfaction. International Journal of Applied Psychology, 2 (5), 98-103.

Millet, P. (2005). Locus of control and its relation to working life: studies from the fields of vocational rehabilitation and small firms in Sweden. Doktorsavhandling, Institutionen för Arbetsvetenskap, Luleå tekniska universitet. Hämtad från http://epubl. ltu. se/14021544/2005/13/LTU-DT-0513-SE. pdf.

Omari, S. M., K’Obonyo, P., \& Kidombo, H. (2012). Human resource practices, the relationship between locus of control and employee outcomes, DBA Africa Management Review, Vol 3 No 1 pp. 90-99.

Reed, S. A., Kratchman, S. H., \& Strawser, R. H. (1994). Job satisfaction, organizational commitment, and turnover intentions of United States accountants: The impact of locus of control and gender. Accounting, Auditing \& Accountability Journal, 7 (1), 31-58. 
Shy, Y., \& Hsin, C. (2013). A Study of External Locus of Control on Relationships among Coping Behavior on Agency Workers Job Satisfaction. Journal of International Management Studies, 8 (2), 54-65.

Singh, A. P., \& Dubey, A. K. (2011). Role of stress and locus of control in job satisfaction among middle managers. The IUP Journal of Organizational Behavior, 10 (1), 42-56.

Spector, P. E., Cooper, C. L., Sanchez, J. I., O'Driscoll, M., Sparks, K., Bernin, P., \& Yu, S. (2002). Locus of control and well-being at work: how generalizable are western findings?. Academy of Management Journal, 45 (2), 453-466.

Srivastava, S. (2009). Locus of Control as a Moderator for Relationship between Organisational Role Stress and Managerial Effectiveness. Vision: The Journal of Business Perspective, 13 (4), 49-61.

Srivastava, S. (2011). Job burnout and managerial effectiveness relationship: Moderating effects of locus of control and perceived Organisational support: An empirical study on Indian managers, Asian Journal Of Management Research, 2 (1), 329-347.

Vijayashree, L., \& Jagdischchandra, M. V. (2011). Locus of control and job satisfaction: PSU employees. Serbian Journal of Management, 6 2), 193-203.

Wang, Q., Bowling, N. A., \& Eschleman, K. J. (2010). A meta-analytic examination of work and general locus of control. Journal of Applied Psychology, 95 (4), 761-268. 